\section{Construction of an Inter- nal Control to Quantitate Multiple Porcine Cytokine mRNAs by RT-PCR}

BioTechniques 21:868-875 (November 1996)

\section{ABSTRACT}

A multiple internal control was constructed to be used as an exogenously added control in reverse transcription polymerase chain reaction (RT-PCR) for pig cytokines. It consists of $5^{\prime}$ and $3^{\prime}$ primer sequences in the order of $\beta_{2}$ microglobulin $\left(\beta_{2}-m\right)$, IL-1, $I L-4, I L-6, I L-8, I L-2, I L-10, T N F-\alpha, T N F-\beta$ and IFN- $\gamma$. Construction was accomplished by overlapping and extension PCR (OE$P C R)$ utilizing short oligonucleotides. The primers were designed to give two products of different sizes on co-amplification of control and target RNAs by RT-PCR in a single tube. This permits analysis of message for several cytokines using a single exogenously added competitive template. Incorporated endonuclease sites allow construct modification by oligonucleotide addition.

\section{INTRODUCTION}

In studies of cytokines, reverse transcription polymerase chain reaction (RT-PCR) obviates bioassay-associated difficulties that are due to pleiotropic, redundant and additive effects. In RTPCR, endogenous or exogenous controls have been used for semiquantitative or quantitative evaluations of gene expression. Endogenous controls such as $\beta_{2}$ microglobulin $\left(\beta_{2}-\mathrm{m}\right)$ or $\beta$ actin are either co-amplified with the target or amplified separately $(6,7)$. Comparison of target and reference transcripts provides a semiquantitative analysis. Exogenous controls, such as competitive DNA or RNA templates have been used as internal controls. However, competitive PCR is influenced by variations in control and target reverse transcription efficiency (3). If heteroduplexes form between competitive template and target sequences, they may interfere with quantitation (7). Reliable quantitation of mRNA can be achieved by using RNA as an internal control and performing RT-PCR for control and target transcripts simultaneously. Generally, internal controls have been constructed by overlapping and extension PCR (OE-PCR) utilizing 2 to 4 synthetic strands. However, errors occur in synthesis, especially of long oligonucleotides. This paper describes a versatile method of internal control construction utilizing short oligonucleotides.

\section{MATERIALS AND METHODS}

\section{Construction of an Internal Control}

An internal control to be used as an 


\section{Short Technical Reports}

Table 1. Primer Sequences of Genes for Procine Cytokines Used for Exogenous Control in Q-RT-PCR

\begin{tabular}{|c|c|c|c|c|c|}
\hline \multirow[b]{2}{*}{ Cytokine } & \multicolumn{2}{|c|}{ Primer Sequence $\left(5^{\prime}-3^{\prime}\right)$} & \multicolumn{2}{|c|}{ Product Size (bp) } & \multirow{2}{*}{$\begin{array}{l}\text { GenBank } \\
\text { Accession \# }\end{array}$} \\
\hline & Forward & Reverse & Control & Target & \\
\hline$\beta_{2}-m$ & CTGCTCTCACTGTCTGG & ATCGAGAGTCACGTGCT & 416 & 284 & L13854 \\
\hline IL-1 & CAGCTATGAGCCACTTCCTG & GTCACAGGAAGTTGCGAATC & 219 & 434 & $X 52731$ \\
\hline IL-2 & CAGTAACCTCAACTCCTGCCAC & CATCCTGGAGAGATCAGCATTC & C 223 & 199 & X58428 \\
\hline IL-4 & GTCTCACATCGTCAGTGC & TCATGCACAGAACAGGTC & 217 & 359 & L12991 \\
\hline IL-6 & GGAACGCCTGGAAGAAGATG & ATCCACTCGTTCTGTGACTG & 219 & 470 & M80258 \\
\hline IL-8 & TGCAGCTTCATGGACCAG & GTACAACCTTCTTCTGCACC & 219 & 323 & $\mathrm{X} 61151$ \\
\hline IL-10 & GCTCTATTGCCTGATCTTCC & GСАСТСТTСАССТССТССАС & 221 & 404 & L20001 \\
\hline TNF- $\alpha$ & CACTGAGAGCATGATCCGAG & GGCTGATGGTGTGAGTGAGG & 221 & 463 & X57321 \\
\hline TNF- $\beta$ & ATGACACCACCTGGACG & TGGTACACAGAGCGCAC & 218 & 502 & X54859 \\
\hline IFN- $\gamma$ & TGTACCTAATGGTGGACCTC & TCTCTGGCCTTGGAACATAG & 221 & 378 & X53085 \\
\hline
\end{tabular}

exogenously added competitive RNA template was constructed utilizing five prime construct (FPC) and three prime construct (TPC) based on cDNA/genomic DNA sequences available in GenBank $^{\circledR}$. The FPC represents the upstream primer sequences of nine cytokine genes sequentially in the order of IL-1, IL-4, IL-6, IL-8, IL-2, IL-10, TNF- $\alpha$, TNF- $\beta$ and IFN- $\gamma$. The TPC has the downstream primers in the same order. When control RNA is coamplified with target RNA, the primers give two products of different sizes (Table 1). Six oligonucleotides of 43 to 58 bases containing 20-nucleotide overlaps were used for each construction. Primers were synthesized (The University of Calgary Core DNA Services, Calgary, AB, Canada) and used to produce complete internal control constructs by a two-step OE-PCR using a DNA Thermal Cycler 480 (PerkinElmer, Mississauga, ON, Canada). The first PCR generated full-length FPC and TPC templates according to the method of Dillon and Rosen (2). Amplifications were accomplished by using the nucleotide overlaps in the oligonucleotides (Figure 1A, 1-6) as primers. The reaction mixture consisted of $50 \mathrm{mM} \mathrm{KCl}, 10 \mathrm{mM}$ Tris-HCl, $\mathrm{pH}$ 8.0, $1.5 \mathrm{mM} \mathrm{MgCl} 2,200 \mu \mathrm{M}$ dNTPs, $0.5 \mu \mathrm{g}$ of each oligonucleotide (1-6) and $2.5 \mathrm{U}$ of Taq DNA Polymerase

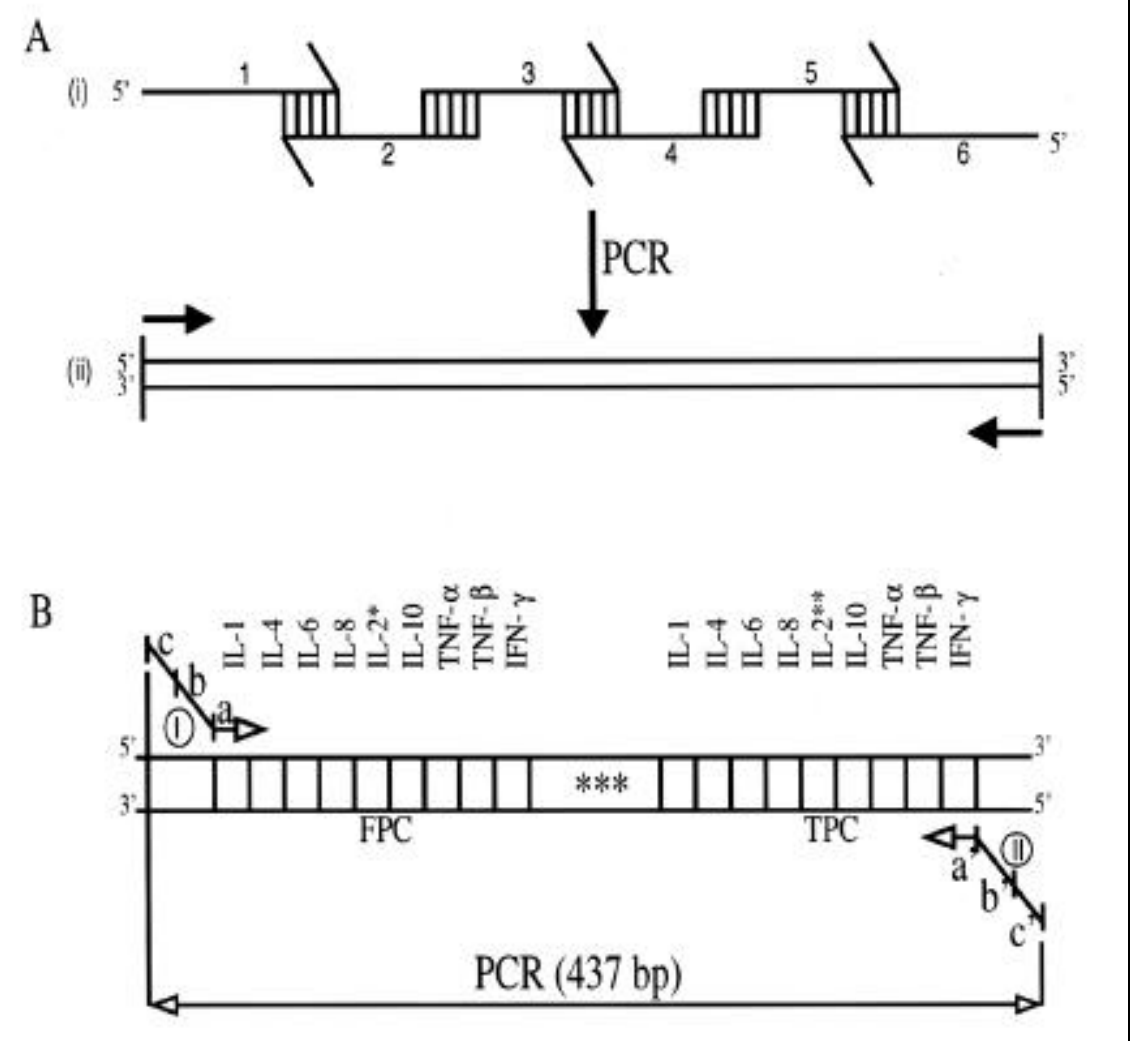

Figure 1. Schematic representation of internal control construction. (A) Five prime (FPC) and three prime (TPC) constructs each utilizing six short oligonucleotides were produced in two steps by PCR. Nucleotide overlaps served as primers to generate full-length templates in a first-round PCR (i), while construct-specific primers were used for amplification in second-round PCR (ii). (B) Addition of housekeeping gene sequences. The nucleotide sequences were incorporated into the existing constructs (FPC and TPC) using two oligonucleotides (I and II) by PCR. The sequences for forward (a) and backward primers ( $\mathrm{a}^{\prime}$ ) for amplification; $\beta_{2}$-m upstream (b) and downstream ( $\mathrm{b}^{\prime}$ ) primers and HindIII (c) and $B g l \mathrm{III}\left(\mathrm{c}^{\prime}\right)$ sites are indicated in oligonucleotides I and II, respectively. * KpnI; **ClaI; ***HincII, XbaI and BamHI. 


\section{Short Technical Reports}

(Life Technologies, Burlington, ON, Canada) in $100 \mu \mathrm{L}$ volume. The cycling conditions were: denaturation $\left(94^{\circ} \mathrm{C}\right.$ for $\left.7 \mathrm{~min}\right)$; annealing $\left(55^{\circ} \mathrm{C}\right.$ for 2 min) and extension $\left(72^{\circ} \mathrm{C}\right.$ for $\left.3 \mathrm{~min}\right)$ for one cycle plus seven additional cycles [denaturation $\left(94^{\circ} \mathrm{C}\right.$ for $\left.1.5 \mathrm{~min}\right)$; annealing $\left(55^{\circ} \mathrm{C}\right.$ for $\left.2 \mathrm{~min}\right)$ and extension $\left(72^{\circ} \mathrm{C}\right.$ for $\left.\left.3 \mathrm{~min}\right)\right]$. In the second step, one $\mu \mathrm{L}$ of the first PCR product was used as template for the secondround PCR, and FPC and TPC templates were amplified using flanking primers specific for each construct (Figure 1A). All reactions were under the following conditions unless otherwise indicated: the reaction mixture was $1 \times$ PCR buffer $(50 \mathrm{mM} \mathrm{KCl}, 20$ $\mathrm{mM}$ Tris-HCl, pH 8.4), $200 \mu \mathrm{M}$ dNTPs, $1.5 \mathrm{mM} \mathrm{MgCl}_{2}, 0.5 \mu \mathrm{M}$ of each $5^{\prime}$ and $3^{\prime}$ primers and $2.5 \mathrm{U}$ Taq DNA Polymerase (Life Technologies) in $100 \mu \mathrm{L}$. Amplifications were for 25 cycles comprising denaturation $\left(94^{\circ} \mathrm{C}\right.$ for $1 \mathrm{~min})$, annealing $\left(55^{\circ} \mathrm{C}\right.$ for $\left.1 \mathrm{~min}\right)$ and extension $\left(72^{\circ} \mathrm{C}\right.$ for $\left.1 \mathrm{~min}\right)$ plus final extension $\left(72^{\circ} \mathrm{C}\right.$ for $\left.10 \mathrm{~min}\right)$. The PCR products were resolved by ethidium bromide-stained $2 \%$ agarose gel electrophoresis, purified and cloned into the pSP64Poly(A) vector (Promega, Madison, WI, USA). Correct orientation was confirmed by PCR using IL2 flanking primers.

Plasmid was column-purified (Qiagen, Chatsworth, CA, USA), cesium chloride gradient-separated and sequenced (Mobix, Hamilton, ON, Canada). One mismatch ('A' for ' $G$ ') detected in TPC was corrected by sitedirected mutagenesis using "hot-start" PCR.

\section{Assembly of $\boldsymbol{\beta}_{2}$-m Primers}

Two oligonucleotides (I and II), each of about 40 bases, were incorporated into the existing constructs (FPC and TPC) by "hot-start" PCR. The oligonucleotides contained the sequences for forward and backward primers for amplification, $\beta_{2}-\mathrm{m}$ flanking primers and endonuclease sites for cloning (Figure 1B). Amplification was performed for 25 cycles in $100 \mu \mathrm{L}$ volume consisting of $1 \times$ cloned Pfu buffer [20 $\mathrm{mM}$ Tris- $\mathrm{HCl}, \mathrm{pH} 8.8,10 \mathrm{mM} \mathrm{KCl}, 10$ $\mathrm{mM}\left(\mathrm{NH}_{4}\right)_{2} \mathrm{SO}_{4}, 2 \mathrm{mM} \mathrm{MgSO} 4,0.1 \%$ Triton ${ }^{\circledR} \mathrm{X}-100,100 \mu \mathrm{g} / \mathrm{mL}$ bovine serum albumin (BSA)], $200 \mu \mathrm{M}$ dNTPs, $100 \mathrm{ng}$ plasmid DNA, $0.5 \mu \mathrm{M}$ of each primer and $2.5 \mathrm{U}$ of recombinant $P f u$ DNA Polymerase (Stratagene-PDI BioScience, Aurora, ON, Canada). Each cycle comprised denaturation $\left(95^{\circ} \mathrm{C}\right.$ for $1 \mathrm{~min})$; annealing $\left(55^{\circ} \mathrm{C}\right.$ for $\left.1 \mathrm{~min}\right)$, extension $\left(72^{\circ} \mathrm{C}\right.$ for $\left.1 \mathrm{~min}\right)$ and a final extension step $\left(72^{\circ} \mathrm{C}\right.$ for $\left.10 \mathrm{~min}\right)$. Bluntend PCR products were resolved by $1.5 \%$ agarose gel electrophoresis, cloned into the pSP64Poly(A) vector and sequenced. 


\section{RESULTS AND DISCUSSION}

We have described a method to construct internal controls for use in quantitative RT-PCR (Q-RT-PCR). Controls have been constructed by OE-PCR, stepwise linking and annealing of PCR primers $(1,4,5)$. Our initial attempts to design and produce a control using more conventional methods involving two overlapping oligonucleotides of about 120 bases resulted in eight mismatches in the two PCR products of about $200 \mathrm{bp}$ each (unpublished results). The errors that occurred after 50 nucleotides from the $5^{\prime}$ end, included three single base deletions of $\mathrm{G}$ or $\mathrm{A}$ and five misincorporations of $\mathrm{G}$ for $\mathrm{A} / \mathrm{C}$; $\mathrm{T}$ for $\mathrm{C}$ or $\mathrm{A}$ for $\mathrm{T}$. The observed error rate of $2 \%$ was greater than the anticipated $0.026 \%$ (4), and synthesis of long oligonucleotides may be error prone. Although primer annealing occurred using this construct, we wished to avoid possible variables in the co-amplification of target and controls in Q-RT-PCR that are due to known primer sequence errors. A primer system was therefore constructed utilizing six short oligonucleotides each of about 50 bases. These had only one mismatch (16th position in the terminal strand of TPC) possibly due to an amplification error by Taq DNA polymerase. Misincorporations were not detected when $P f u$ DNA polymerase was used.

Several enzyme sites were either retained or incorporated into the construct to facilitate insertion of additional sequences. Since quantitation of target genes by RT-PCR is sensitive to variations in actual gene expression but also to qualitative variation in the target RNA, it was decided to use a constitutively expressed "housekeeping gene" as a within-sample reference. The internal control was therefore modified by incorporating $\beta_{2}-\mathrm{m}$ sequences. Target gene values can be normalized to $\beta_{2}-\mathrm{m}$ reference transcripts to correct for between-sample variations arising within the starting RNA. Since the control contains the flanking primer sequences of multiple cytokines, a single control can be used as a competitive template in Q-RT-PCR to analyze several cytokines in each sample. In the authors' hands, the method has proven useful in quantifying expression of the targeted pig cytokine genes in blood cells.

\section{REFERENCES}

1.Benavides, G.R., B. Hubby, W.M. Grosse, R.A. McGraw and R.L. Tarleton. 1995. Construction and use of multi-competitor gene for quantitative RT PCR using existing primer sets. J. Immunol. Methods 181:145-156.

2.Dillon, P.J. and C.A. Rosen. 1990. A rapid method for the construction of synthetic genes using the polymerase chain reaction. BioTechniques 9:298-300.

3.Ferre. F., A. Marchese, P. Pezzoli, S. Griffin, E. Buxton and V. Boyer. 1994. Quantitative PCR: an overview, p 67-88. In K.B. Mullis, F. Ferre and R.A. Gibbs (Eds.), The Polymerase Chain Reaction, Birkhauser, Boston.

4.Ho, S.N., H.D. Hunt, R.M. Horton, J.K. Pullen and L.R. Peare. 1989. Site-directed mutagenesis by overlap extension using the polymerase chain reaction. Gene 77:51-59.

5.Kanangat, S., A. Solomon and B.T. Rouse. 1992. Use of quantitative polymerase chain reaction to quantitate cytokine messenger RNA molecules. Mol. Immunol. 29:1229-1236.

6.Kinoshita, R., J. Imamura, H. Nagai and K. Shimotohno. 1992. Quantification of gene expression over a wide range by the polymerase chain reaction. Anal. Biochem. 206: 231-235.

7.Murphy, L.D., C.E. Herzog, J.B. Rudick,
A.T. Fojo and S.E. Bates. 1990. Use of the polymerase chain reaction in the quantitation of $m d r-1$ gene expression. Biochemistry 29: 10351-10356.

Received 4 December 1995; accepted 17 May 1996.

The authors gratefully acknowledge the advice of Drs. Carlton L. Gyles and Stephani A. DeGrandis and support from the Natural Sciences and Engineering Research Council of Canada. Address correspondence to Bruce N. Wilkie, Department of Veterinary Microbiology and Immunology, Ontario Veterinary College, University of Guelph, Guelph, Ontario, Canada N1G 2W1. Internet: bwilkie@uoguelph.ca

N.R. Jayagopala Reddy, Bruce N. Wilkie and Bonnie A. Mallard

Ontario Veterinary College

University of Guelph

Guelph, ON, Canada 